\title{
Gandhism in Contemporary Nepali Poems
}

\author{
Govind Thapa Chetry \\ Department of Hindi, Central University of Himachal Pradesh, Himachal Pradesh, India \\ Corresponding author: govind19424u@gmail.com
}

Received: 19 Jan., 2019

Revised: 17 Apr., 2019

Accepted: 27 May, 2019

\begin{abstract}
Truth, non-violence and love are at the centre of Mahatma Gandhi's philosophy, which is also the basis of this philosophy. Truth, non-violence and love established by Gandhi are interlinked, which cannot be separated. Non-violence has been the tool and the truth has been the goal in Gandhism. Gandhiji believed in 'Ahimsa Paramodharma', that is, non-violence is the ultimate dharma. Contemporary Nepali poets have presented different aspects of Gandhi's principles in their respective poems. At the same time, poets have realized the need of Gandhi's thoughts, philosophy and principles in today's time were the amount of tainted humanity and violent tendency in humans are increasing. Human values are slowly declining from the society we live in today. Therefore, at this time, Gandhian philosophy, ideology and principles become very important and useful, who teaches the text of world peace, non-violence, love, truth, universal religion, selfreliance and love. Contemporary Nepali poets have also recognized the need of the time and made Gandhi philosophy and principles a part of their poetry, through which society can be shown the right path.
\end{abstract}

Keywords: Gandhian philosophy, human values, Nepali poems

The ideology of Mahatma Gandhi's principles of truth, non-violence, love, trusteeship, Sarvodaya, change of heart and Satyagraha is called Gandhism. According to Gandhi - "My philosophy which you have named Gandhism is rooted in truth and non-violence." Gandhi Ji believed that there was no existence of anything other than the truth. This is the truth on the strength on which the existence of an object is published and proven. He believed that truth is God. "Gandhi Ji, who was always a working man, continued to define God in practical ways through which he can be reached (Truth is God, obeying truth will lead me to God, so God means to me now and here; whatever nature God ultimately has, Gandhi believes that he (Gandhi) has to be truthful) not in the form of a subtle thought (i.e. God is true)."

Gandhi Ji while explaining the truth has said that truth is not available through logic. This is the perceived truth, that is, the truth can be achieved only through our own internal experience. Truth is beneficial and brings welfare to one and all and nobody can be denied of it. The truth, with which one is to be harmed, damaged or put to loss cannot be the truth. "No systematic classical study like Marxism is behind Gandhism, which is why it lacks any kind of logical method. Its basis is selfperception, not logic. Each section of this ideology carries with it self-power. For this reason, there is a kind of spirituality and freedom of thought". ${ }^{3}$ Nonviolence is the essential element for the attainment of truth. Only a non-violent can be a true seeker of truth. Therefore it proves that the only way for a person or seeker to follow the path of truth is the path of non-violence. This is the reason why Gandhi Ji considered non-violence to be an essential part of the truth and gave special emphasis on the realization of the truth that is possible only through 
non-violence. Ahimsa is the tool and the truth is the goal. If one has to choose between truth and nonviolence, he must always choose the truth without any hesitation. He can also sacrifice non-violence for the truth. But one cannot abandon the truth for anything in the world. In Gandhi's view, achieving India's freedom by walking on the path of truth and non-violence was not the only goal, but it had a moral significance for the whole world at its core. Giving a message to the world, Gandhi says- "If India attains freedom on the strength of truth and non-violence, then I am confident that this will be the biggest contribution of this era in the field of world peace."

Gandhiji's life is the path to the practice of truth, his truth is not the source of any religion or sect, but the essence of many religions of the world lies in it. Ahimsa is a vision which Gandhi Ji has independently associated with truth - "Ahimsa is my god and truth is my god. When I seek non-violence, then the truth says find non-violence through me. And when I want to find the truth, then non-violence says to find out the truth through me." Gandhiji's non-violence was associated with mind, deeds, and words. "Nokilling' in this sense, Ahimsa was a part of the Hindu-Jain tradition of Gandhiji's own state Gujarat. But in the form of Gandhism, the term took on a new, deeper and wider meaning. In the negative form, it now means "to refrain hurting the earth in thought, word, and deed." In positive terms, "this is not only a negative state of harmlessness but a positive state of love and good towards the evildoers." The principle of non-violence is a universal principle. Depiction of the principle of this non-violence is also seen in the poem 'Yugantar' of Nepali poet Nav Sapkota-

\section{Ājalē yahān yuddha hōina śhānti khōjēkō cha / tyasailē \\ tì khukurī larkā'ì banduka bhirī \\ dharatī tharkā'unē \\ palanèlā̄ èuā arjī \\ timì tyō bāō najā'u \\ juna bāō mānisa kō phūlabārī pugincha.}

(That is, here peace is needed today, not war, so a request to the soldiers who took the Khukuri and the gun to shake the earth, do not go through the path that reaches the tomb).

According to Gandhi, non-violence is another form of love. Where there is love, there will definitely be non-violence and where there is non-violence, there is no love, it cannot happen. Therefore it is clear that truth, non-violence, and love are interlinked with each other. But in present-day truth, non-violence and love are seen to be dimness. Avinash Shrestha's poem 'Karodon Suryaharuko Andhakar' confirms this, one example -

Lupta hunēcha èka dina mānchēkō prajāti

tara tyasabhandā agāi nai lupta hūmdai cha- mānavatā luptaprāya: Cha udāratā

lōpa hūmdai cha- viśvāsa, sānchō sadbhāva

lōpōnmukha cha- vinamratā

abōdha pavitratā!

(That is, one day the species of man will disappear, but before that - humanity is disappearing. Generosity is disappearing. Disappearing - Faith and true goodwill. Modesty and innocent purity on the verge of extinction).

Swaraj founded by Mahatma Gandhi is not just a movement but a dream and an idea. The concept of ideal and proper governance over itself is also Swaraj. According to Gandhi, Swaraj is a sacred word, it is a Vedic word which means self-discipline and self-control. Swaraj in the real sense is the rule which runs according to the public consensus. Where there is no place of ethnic and religious discrimination. Gandhi Ji raised the slogan of Village Swaraj and Gandhi Ji was the first person to say 'Hindustan is the country of the village'. He wanted the villages to become self-sufficient, to meet their minimum requirements, and not depending on cities. But in today's scenario, the basic agricultural system of the country has collapsed. Because of the debt, famine, and hunger the condition of the farmers are becoming pathetic and they are being forced to commit suicide. An example illustration from Rajendra Bhandari's poem 'Gaonko Serofero' highlighting this -

Bhōk ra ātmahatyā,

khaērī ra paihtrō,

rira mahājankō sarpa

gāonmā guulki'ēkai thiyō. 
(That is, hunger and suicides, drought and floods, debt and sank of moneylenders are sitting in the village).

Gandhiji's religion was 'Sarvadharma Sambhav Dharma'. He was in favor of and support of intercaste and inter-religious marriages. Today, at the present time, caste and religious differences exist like termites in the country. An example from Dinesh Adhikari's poem 'Aashanka' is illustrative -

Dharmakō āamā hō'inā

yō paaka'jāta' kō kāraa

ma phēri'achūta' pō hunchu ki?

Phailindai jāmdā yō ghrākō via

(That is, not under the guise of religion, this time due to 'caste' will I become 'untouchable' again? This poison of hate is being spread).

Gandhi does not accept untouchability as part of Hinduism but considers it a sin and believes that removing it from our society is the religious and absolute duty of every Hindu. "If I have to take birth again, I should not be born as a Brahmin, Kshatriya, Vaishya or Shudra, but born as a very Shudra."

The principle of Gandhiji's change of heart was to change one's heart in the sense of service, without the use of force and without any pressure. Truth and non-violence are its paths. The theory of change of heart was especially for the rich and the capitalists. 'Sarvodaya', which means the rise of all, development of all, wellness of all and welfare of all. Its ultimate goal is the rise and well-being of the last person (Antodaya). Everyone's uplift lies in it. Gandhi Ji has spoken of two types of rise, first internal which can also be called spiritual and second physical. Gandhi Ji has spoken of the first internal rise and upliftment, later the external development. The restraint, satisfaction, patience that Gandhi Ji has spoken is reflected in the poetry of Nepali poets -

Usakō sahanaśîlatā sabaikō bhandā biśāla cha.

Usakō kamāsílatā sabaikō bhandā bahī udāra cha.

Yahī sahiutākō kāraalē hōlā

sadhēādhā pēa rahē pani mukhamā cēhē rāma! Cha! Hē

rāma! Cha!
(That is, his tolerance is the greatest. His forgiveness is the most generous. It will be because of this tolerance, after having half stomach, he is mouth still chanting, O! Ram! O! Ram!).

In conclusion, Mahatma Gandhi was such a great man, whose principle of truth, non-violence, and love had an impact not only in India but on the whole world. Truth, non-violence, and love were at the core of Gandhiji's principles. In which he believed the truth to be paramount. The poems of contemporary Nepali poets also could not remain untouched by these great principles. Gandhism appears directly or indirectly in Nepali poems. Meen Bahadur Bisht's poem 'maun, matra maun, bilkul maun' depicts the ideas of truth, non-violence, love, universal religion, humanity, etc. established by Gandhi -

\section{Allāhakō pratīka āyātullāha pani thiyō \\ śāntikō pratīka gautama pani thiyō \\ ahinsākō pratīka gāndhī pani thiyō \\ gìtā thiyō, bā'ibala thiyō, kurānasamēta thiyō \\ sanskrti thiyō, vijñāna pani thiyō.}

(That is, Ayatullah the symbol of Allah was also there, Gautama Buddha the symbol of peace was also there, Gandhi the symbol of non-violence was also there, the Gita was there, the Bible was there with the Quran. There was culture, there was also science).

Contemporary Nepali poets have presented different aspects of Gandhi's principles in their respective poems. At the same time, poets have realized the need of Gandhi ji's thoughts, philosophy and principles in today's time were the amount of tainted humanity and violent tendency in humans are increasing.

\section{REFERENCES}

Adhikari, Dinesh, Aashanka, Kavita Kosh, Kavitakosh.org.

Bhandari, Rajendra 2010. Gaonko Serofero, Shabdaharuko Punarwas, Prakashak Sikkim Sarkar, Gantok, 10.

Bisht, Meen Bahadur, Maun, Matra Maun, Bilkul Maun, Kavita Kosh, kavitakosh.org. 
Dr. Amarnath 2013. Hindi Alochana ki Paribhashik Shabdawali, Rajkamal Prakashan, 143.

Gandhi, Mahatma 1972. Sampurn Gandhi Vangmaya, Vol-48, Prakashan Vibhag, Suchana evam Prasaran Mantralaya, Bharat Sarkar, 01.

Harijan, 26 March 1936.

Nav, Sapkota 1996. Kavyantar, Yugantar, Nepali Sahitya Parishad, 37.

Ramsharan, Prahlad 2017. Mahatma Gandhi aur Mauritius par Unka Prabhaw, Star Publication, 135.
Ramsharan, Prahlad 2017. Mahatma Gandhi aur Mauritius par Unka Prabhaw, Star Publication, 135.

Shrestha, Avinash 2003. Karodon Suryaharuko Andhakar, Kaalchakr Prakashak, Nepal, 52-53.

Syangden, Norjang 2001. Raag-Rantharuma, Saanjha Pustak Prakashan, 52.

Young India, $4^{\text {th }}$ July 1925.

Young India, $4^{\text {th }}$ may 1921. 